\title{
Penerapan Inovasi Teknologi Mesin Penggorengan Vakum dan Pelatihan Olahan Kripik Buah di Kelompok Usaha Bersama(Kub) Ayu di Kelurahan Kranjingan Kecamatan Sumbersari Kabupaten Jember
}

\author{
Application of Innovation of Vacuum Frying \\ Machine Technology and Fruit Chips \\ Processing Training at Ayu Group of Business \\ (Kub) in Kranjingan Sub-District, Sumbersari \\ Sub-district, Jember District
}

\author{
Hesti Herminingsih \\ Program Studi Agribisnis Fakultas MIPA UPBJJ UT Jember \\ hestih@ecampus.ut.ac.id
}

\begin{abstract}
The objective of Community Service Scheme Program for Community in KUB Ayu Kelurahan Kranjingan is to assist partner business groups in their efforts to improve partner productivity through the application of appropriate technology and business management training. Problems related to the production process faced by partners are 1) food frying is still done by traditional way, and 2) Partners difficulty in managing financial administration, management of raw material stock control, management of stock control of finished material. Motode in the manufacture of vacuum frying machine (Vacuum Frying Machine) begins with the process of planning, manufacturing, testing, and training the use of machinery for members of partners. The implementation method consists of 4 stages, the first coordination and socialization of the activity plan, the two identification and validation of partner

problems, the three design, assembly, and field test of equipment and machinery according to the needs of partner technology, the four counseling and mentoring. The result of Community Science and Community Service program can realize the implementation of vacuum fryer machine with specification of raw material capacity $3 \mathrm{~kg} / \mathrm{process}$, LPG fuel with automatic temperature control, water circulation coolant, cooking oil volume: 35 liters, power requirement 900 watt, 180 dimension $X 120 \times 120 \mathrm{~cm}$, with an oil heating temperature range of $800 \mathrm{C}$ to $870 \mathrm{C}$. The frying time ranges from 90-120 minutes. Variations of chips raw materials include; Jackfruit, pineapple, with depreciation rates of $70 \%, 60 \%$ and $80 \%$, respectively. Training of financial administration management skills, management of raw material stocks, management of finished material stock control has brought social and economic impact to KUB Ayu's partners.
\end{abstract}

Keyword : Training of fruit chips, Vacuum Frying Machine, KUB Ayu.

\section{PENDAHULUAN}

\subsection{Analisis Situasi}

Penguatan kelompok usaha bersama berbasis sumberdaya lokal merupakan salah satu upaya strategis untuk medorong kemandirian, produktifitas dan daya saing ekonomis daerah.
Seperti halnya, Kelompok Usaha Bersama "Ayu" adalah usaha skala rumah tangga yang memproduksi bahan pangan kemasan seperti; ladrang, keripik pisang (manis/asin), sale goreng dan kuping gajah. KUB "Ayu” memulai usahanya sejak tahun 2001 dengan jumlah anggota 16. Pada tahun 2012, KUB 
Hesti Herminingsih. Faktor Produksi Usaha Ternak Itik Petelur Semi Intensif Di Kabupaten Jember.

'Ayu" telah memiliki sertifikat halal MUI dan ijin PIRT dengan nomor; 2143509090161-19. Hasil produksi KUB "Ayu" dipasarkan dengan metode konsinyasi di sejumlah toko yang menjual makanan oleh-oleh. Wilayah pemasarannya meliputi; Kabupaten Jember, Kabupaten Bondowoso dan Kabupaten Situbondo.

Salah satu rangkaian proses produksi KUB "Ayu" proses penggorengan. Proses penggorengan yang dilakukan masih konvensional yaitu dengan menggunakan wajan dan minyak goreng pada suhu tinggi. Cara ini dilakukan karena pertimbangan biaya yang cukup murah dan ekonomis serta waktu yang diperlukan relatif singkat.

Minyak goreng dalam proses penggorengan berfungsi sebagai medium penghantar panas, menambah rasa gurih, menambah nilai gizi dan kalori dalam bahan pangan. Penggorengan yang dilakukan dengan cara konvensional umumnya menyebabkan minyak mengalami kontak langsung dengan KUBara. Kontak langsung minyak dengan KUBara merupakan penyebab utama kerusakan minyak goreng (Ketaren.S, dalam Aswan 2012 ).

Penggorengan yang dilakukan dengan suhu tinggi menyebabkan minyak mengalami proses oksidasi dan polimerasi. Minyak yang rusak akibat proses oksidasi dan polimerisasi akan mempengaruhi kualitas mutu dan nilai gizi bahan pangan yang digoreng. Penurunan

kualitas yang dimaksud meliputi warna dan tampilan yang kurang menarik, perubahan cita rasa, dan kerusakan sebagian vitamin dan nutrisi yang dikandung baik dalam minyak maupun bahan pangan itu sendiri. (Ketaren. S, dalam Aswan 2012). Pemilihan suhu penggorengan merupakan faktor yang menentukan mutu hasil gorengan, yang dinilai berdasarkan rupa, flavor, lemak yang terserap dan stabilitas penyimpanan serta faktor ekonomi. Mutu hasil gorengan dengan stabilitas penyimpanan yang baik dihasilkan pada suhu menggoreng yang paling rendah. Penggunaan suhu yang lebih rendah dapat memperbaiki mutu hasil gorengan, namun cara ini jarang diterapkan karena pertimbangan ekonomis.

Kelebihan penggorengan vakum dibandingkan dengan penggorengan konvensional adalah warna bahan pangan relatif tidak berubah, lebih renyah, tampilan lebih menarik, lebih tahan lama dan rasa yang lebih enak. Karakteristik produk yang seperti inilah yang lebih disukai oleh konsumen. Selaian itu, Penggorengan vakum menjadikan kandungan gizi bahan pangan seperti protein, lemak, dan vitamin tetap terjaga. Sistem penggorengan vakum akan menghasilkan produk yang kering dan renyah, tanpa mengalami kerusakan nilai gizi dan flavor seperti halnya yang terjadi pada penggorengan konvensional.

Keterbatasan SDM yang dimiliki KUB Ayu dalam menjalankan usaha tanpa adanya catatan dan pengelolaan administrasi keuangan usaha yang tertib dan manajemen persediaan bahan baku dan bahan jadi yang baik. Akibatnya, mitra sering tidak dapat mengetahui dengan pasti keuntungan yang diperoleh, jumlah modal atau biaya yang diperlukan. Informasi tersebut menjadi sangat penting manakala sebuah usaha akan memperluas usahanya.

Kesulitan lainnya adalah pengelolaan manajemen persediaan bahan baku dan bahan jadi. Pada bulan-bulan tertentu mitra mengalami kekurangan bahan baku maupun produk jadi. Hal ini menyebabkan tidak dapat terpenuhinya permintaan pasar dengan optimal. Persediaan bahan baku dan bahan jadi sangat penting sekalipun bagi usaha skala kecil. Kedua kelompok mitra mengakui tidak berani menyimpan produk jadi terlampau banyak karena takut merugi jika produk tidak laku. Manajemen persediaan terutama produk jadi yang saat ini dilakukan oleh kedua kelompok mitra hanya didasarkan pada pengalaman selama menjalankan usaha.

Keberadaan persediaan dalam sebuah usaha memiliki tujuan penting. Alasan utamanya adalah tidak selamanya sumber daya tertentu dapat didatangkan ketika sumber daya tersebutdibutuhkan. Sehingga, untuk menjamin ketersediannya diperlukan persediaan yang siap digunakan ketika dibutuhkan. Pengendalian persediaan dalam sebuah usaha sangat penting dilakukan. Hal ini bertujuan untuk menjamin terdapatnya persediaan sesuai

kebutuhan. Pengendalian persediaan untuk jenis usaha kecil umumnya terfokus pada persediaan bahan baku utama dan hasil produksi (barang jadi).

\subsection{Permasalahan Mitra}

Berdasarkan analisis situasi dapat diuraikan beberapa masalah yang dihadapi oleh KUB Ayu dalam meningkatkan usahanya memproduksi aneka cemilan yang terjamin ketersediaanya dan berkualitas baik yaitu;

1. KUB Ayu masih menerapkan cara penggorengan yang digunakan masih tradisional/konvensional sehingga mempengaruhi kualitas produk yang dihasilkan.

2. Belum melaksanakan pengeloaan administrasi keuangan sekalipun secara sederhana. Hal ini menyebabkan infromasi keuntungan yang diperoleh, 
jumlah modal, biaya yang diperlukan dan omzet usaha secara berkala tidak dapat dicatat dan dibukukan dengan mudah. Bahan baku dan produk jadi dilakukan berdasarkan pengalaman pribadi tidak merujuk pada standar teori yang ada sehingga peluang pasar tidak dapat diserap dengan optimal terutama saat permintaan sedang tinggi.

\section{II.TINJAUAN PUSTAKA}

\subsection{Mesin Penggorengan Vakum}

Mesin penggoreng vacum adalah mesin produksi untuk menggoreng berbagai macam buah dan sayuran dengan cara penggorengan vacum. Teknik penggorengan vacum yaitu menggoreng bahan baku (biasanya buahbuahan atau sayuran) dengan menurunkan tekanan udara pada ruang penggorengan sehingga menurunkan titik didih air sampai $50^{\circ}-60^{\circ} \mathrm{C}$. Dengan turunnya titik didih air maka bahan baku yang biasanya mengalami kerusakan/perubahan pada titik didih normal $100{ }^{\circ} \mathrm{C}$ bisa dihindari. Teknik penggorengan vacum ini akan menghasilkan kualitas yang lebih baik dibandingkan dengan cara penggorengan biasa Daryanto, 2003 dalam Sunaryo (2014).

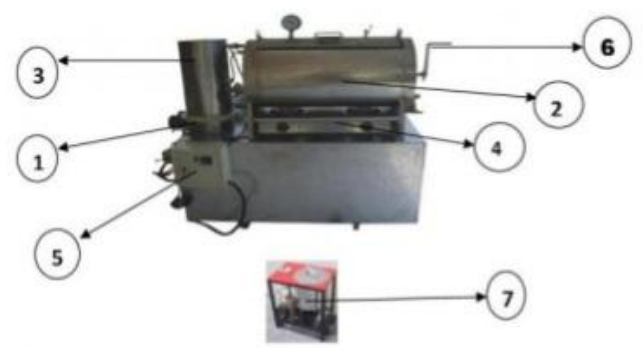

Gambar 1. Mesin Penggorengan Hampa Dan Peniris MINYAK

Sumber: http://anekamesin.com/sistem-vacuumfrying.html

Keterangan gambar:

1. Pompa vacuum water jet, berfungsi untuk menghisap KUBara di dalam ruang penggoreng sehingga tekanan menjadi rendah, serta untuk menghisap uap air dari bahan yang digoreng.

2. Tabung penggoreng, berfungsi untuk mengkondisikan bahan sesuai tekanan yang diinginkan. Di dalam tabung dilengkapi keranjang buah setengah lingkaran.

3. Kondensor, berfungsi untuk mengembunkan uap air yang dikeluarkan selama penggorengan. Kondensor ini air sebagai pendingin.

4. Unit pemanas, menggunakan kompor gas LPG.
5. Unit Pengendali Operasi (Panel Kontrol), berfungsi untuk mengaktifkan alat vacuum dan unit pemanas.

6. Bagian pengaduk penggorengan, berfungsi untuk mengaduk buah yang berada dalam tabung penggorengan. 7. Mesin peniris minyak (Spinner), berfungsi untuk meniriskan kandungan minyak kripik yang sudah jadi.

Mesin penggorengan hampa bekerja dengan menggunakan prinsip Bernoulli (konsep dasar aliran fluida / zat cair dan gas). Dimana semburan air dari pompa yang dilalui pipa menghasilkan efek sedotan (hampa). Dengan menggunakan 7 atau 8 nosel, pipa khusus penghisap KUBara sehingga tekanan di dalam tabung penggorengan turun hingga $7.52 \mathrm{cmHg}$. Pada tekanan $7.52 \mathrm{cmHg}$ titik didih air akan turun menjadi $45,8^{\circ} \mathrm{C}$. Air di dalam tabung penggoreng selanjutnya didinginkan di kondensor dengan sirkulasi air pendingin. Setelah dingin air dimasukkan ke dalam bak air sedangkan uap air yang telah mengalami kondensi ditampung di penampungan kondensat. Aneka Mesin (2012).

Prinsip kerja vacum frying adalah menghisap kadar air dalam sayuran dan buah dengan kecepatan tinggi agar pori-pori daging. buah-sayur tidak cepat menutup, sehingga kadar air dalam buah dapat diserap dengan sempurna. Prinsip kerja dengan mengatur keseimbangan suhu dan tekanan vakum. Faktor - faktor yang mempengaruhi mutu akhir produk yang digoreng adalah kualitas bahan yang digoreng, kualitas minyak goreng, jenis alat penggorengan dan sistem kemasan produk akhir. Selama penyimpanan, produk yang digoreng dapat pula mengalami kerusakan yaitu terjadinya ketengikan dan perubahan tekstur pada produk. Ketengikan dapat terjadi karena minyak/ lemak mengalami oksidasi. Hal ini dipengaruhi oleh mutu minyak, kondisi proses penggorengan dan sistem pengemasan yang digunakan. Pada alat penggoreng vacum ini uap air yang terjadi sewaktu proses penggorengan disedot oleh pompa. Setelah melalui kondensor uap air mengembun dan kondensat yang terjadi dapat dikeluarkan. Sirkulasi air pendingin pada kondensor dihidupkan sewaktu proses penggorengan (Sunaryo, 2014).

\section{METODE PELAKSANAAN}

Pelaksanaan Program Pengabdian Kepada Masyarakat untuk skeme Iptek bagi Masyarakat (IbM) ini merupakan kegiatan yang dilaksanakan 
Hesti Herminingsih. Faktor Produksi Usaha Ternak Itik Petelur Semi Intensif Di Kabupaten Jember.

oleh LPPM Universitas Terbuka dengan pendanaan dari Dirjen DIKTI tahun 2016. Metode pelaksanaan kegiatan ini secara garis besar ada dua tujuan; (1) perbaikan kuantitas dan kualitas produksi usaha mitra dan (2) peningkatan kemampuan manajemen pengelolaan usaha yang lebih professional. Metode pelaksanaan dan proses untuk mencapai target luaran dari kegiatan ini terdiri dari beberapa tahapan.

Tahap pertama adalah melakukan koordinasi dan sosialisasi serta sinkronisasi mengenai rencana kegiatan dengan kelompok usaha mitra. Pada tahap ini semua potensi dan peluang sumberdaya kelompok ditemukenali dan dipadukan dalam rangka persiapan pelaksanaan kegiatan ini. Tahap Kedua adalah melakukan identifikasi dan validasi permasalahan terkait dengan manajemen produksi dan usaha kelompok mitra kebutuhan teknologi yang sesuai dengan spesifik lokasi. Hasil identifikasi tersebut kemudian dijadikan sebagai acuan dalam pengembangan prototipe alat dan mesin yang akan diintroduksikan dan materi pelatihan agar teknologi dan penyuluhan yang dihasilkan nantinya betul-betul dapat membawa manfaat bagi keberlanjutan usaha kelompok mitra serta dapat diinternalisasikan dalam proses adopsi. Beberapa faktor yang dijadikan pertimbangan antara lain kapasitas produksi yang diinginkan, kapasitas alat dan mesin yang dibutuhkan, ketersediaan daya listrik, dan tingkatan teknologi yang dibutuhkan. Tahap ketiga adalah perancangan dan perakitan alat dan mesin yang sesuai dengan kebutuhan teknologi di tingkat kelompok mitra dan pembuatan modul berisi materi penyuluhan yang sesuai dengan kebutuhan kelompok mitra. Setelah perakitan selesai kemudian dilakukan pengujian lapang bersamaan dengan demo dan sosialisasi penggunaan alat dan mesin di tingkat kelompok mitra.Tahap keempat adalah kegiatan dengan penyuluhan dan pendampingan mengenai manajemen usaha agar penguatan kelompok dapat berjalan sesuai dengan target dan kesepakatan bersama mitra. Metode yang dipilih disesuaikan dengan kondisi sosial dan kemampuan serta waktu yang dimiliki anggota seperti diskusi bersama, presentasi maupun metode learning by doing santai tanya jawab yang penting semua dapat berjalan lancar.

\section{HASIL DAN PEMBAHASAN}

Berdasarkan permasalahan diatas dan kesepakatan bersama dengan mitra dirancang beberapa solusi yang mampu meningkatkan mitra dari skala rumah tangga menjadi usaha menengah yang semakin profesional. Kegiatan yang akan dilakukan sebagai alternatif strategi pengembangan usaha diuraikan sebagai berikut;

1. Perbaikan Terknologi Peralatan Produksi

Teknologi peralatan produksi yang masih tradisional perlu diperbaiki. Perbaikan teknologi dilakukan dengan membuat paket teknologi tepat guna berupamesin penggorengan hampa (vacuum frying)yang dilengkapi denganpeniris minyak (spinner) dengan kapasitas produksi $3 \mathrm{~kg}$. Teknologi tepat guna tersebut akan dapat meningkatkan kapasitas produksi dan hasil penggorengan yang berkualitas baik, tahan lama, memiliki rasa dan aroma yang homogen dan memiliki tekstur yang kering karena kandungan minyak yang sedikit.

2. Materi Penyuluhan dan Pendampingan mengenai Teknik Pengemasan Produk

Penyuluhan mengenai teknik pengemasan produk yang baik perlu dilakukan. Kemasan yang baik dapat mencegah produk dari kerusakan lebih lama, mencegah bau tengik. Selain itu, kemasan yang cerah dan menarik dapat mendorong konsumen untuk membeli produk.

3. Pelatihan Manajemen Persediaan dan Administrasi

Pelatihan manajemen persediaan dan administrasi sangat perlu untuk dilakukan kepada seluruh anggota untuk mendukung keberlanjutan usaha secara umum. Pelatihan ini bertujuan untuk memperbaiki aspek pengendalian persediaan barang jadi dan bahan baku utama. Dengan demikian diharapkan kelompok usaha bersama yang tergabung dalam KUB Ayu dapat menjadi usaha home industri yang profesional.

4. Materi Penyuluhan dan pendampingan mengenai Teknik Penyimpanan Produk

Penyimpanan produk sangat penting dalam industri rumah tangga terutama jenis olahan makanan. Penyimpanan bertujuan sebagai stok untuk menjamin ketersedian produk Teknik penyimpanan yang baik akan menghindari produk dari penurunan berat, penurunan kualitas, dan kehilangan nilai uang. Hasil yang diperoleh dari kegiatan IbM ini bagi KUB Ayu adalah tersedianya teknologi tepat guna berupa Mesin Penggorengan Hampa berkapasitas 3 $\mathrm{kg}$ yang dilengkapi dengan

mesin peniris minyak dengan kapasitas yang sama. Pada awal pengoperasian mitra mengalami kesulitan karena mesin tersebut merupakan hal yang baru. Namun dengan bantuan Tim Abdimas dan setelah berkali-kali mencoba, pada akhirnya KUB Ayu 
dapat mengoperasikan mesin penggorengan vakum dengan baik. Praktek Pembuatan Kripik Buah dengan Penggorengan Vakum oleh mitra dapat dilihat pada Gambar 2 sampai dengan Gambar 5.

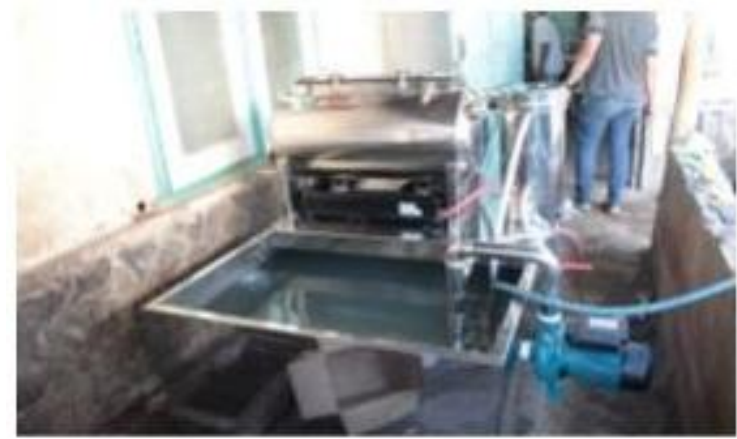

Gambar 2. Mesin PengGorengan VAKum 3 Kg Mitra

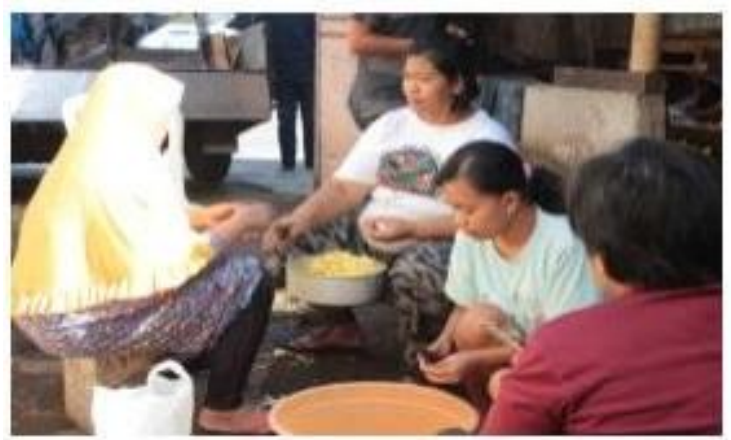

Gambar 3. Persiapan Bahan BAKU

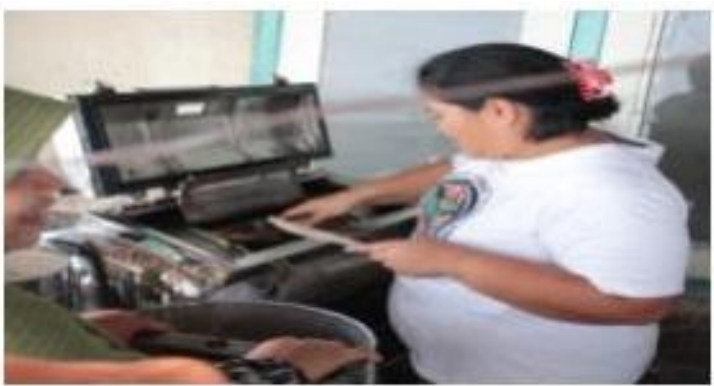

Gambar 4. Praktek Pembuatan Kripik Buah oleh MITRA

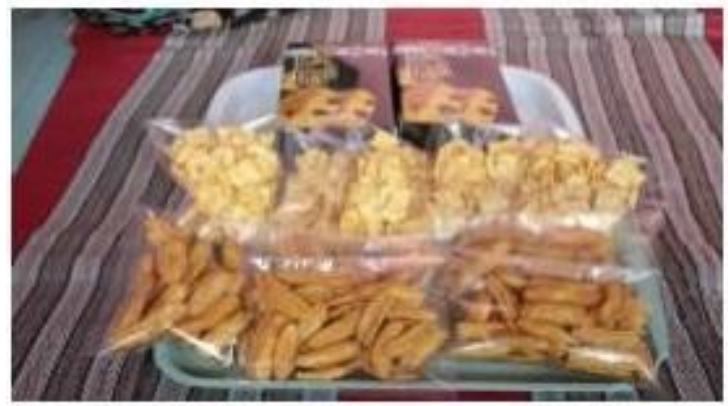

Gambar 5. HaSil Olahan KRIPIK BUAH

Kendala sementara yang dialami oleh KUB Ayu bedasarkan hasil pendampingan dan monitoring selama bulan Agustus-September 2016 adalah kesulitan untuk menentukan bahan baku yang tepat untuk mesin penggorengan vakum. Kendala lainnya adalah upaya untuk mencari pemasaran dan penentuan harga yang optimal dari produk baru tersebut. Bahan baku yang sudah dicoba oleh KUB Ayu adalah pisang mas, nanas, dan nangka. Setelah melalui berbagai pertimbangan dari ketiga bahan baku tersebut maka KUB Ayu memutuskan untuk menggunakan pisang mas sebagai produk baru hasil mesin penggorengan vakum. Berikut hal-hal secara ringkas yang menjadi pertimbangan KUB Ayu memilih bahan baku pisang sebagai kripik dapat dilihat pada Tabel 3.1 :

TABel 3.1 PERTIMBANGAN KUB AYU DALAM PEMILIHAN BAHAN BAKU

\begin{tabular}{|c|c|c|c|}
\hline Traian & nangka & pisang & nanas \\
\hline 1 Harga bahan balku & relatif mahal & terjangkau & relatif mahal \\
\hline $\begin{array}{l}2 \text { Penyusutan bahan balku } \\
\text { memiadi bahanijadi }\end{array}$ & $70 \%$ & $60 \%$ & $80 \%$ \\
\hline 3 Ketersediazn bahan baliu & $\begin{array}{l}\text { musim panen singhat, } \\
\text { harga bahan balun tidakx } \\
\text { menentu. Meniliti } \\
\text { kecenderunganlebih } \\
\text { mahal }\end{array}$ & $\begin{array}{l}\text { musim panen } \\
\text { sepanimngtahun, } \\
\text { harga baharnbalku } \\
\text { relatif murah }\end{array}$ & 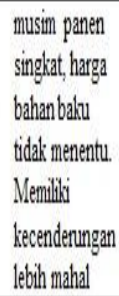 \\
\hline
\end{tabular}

No Uraian nangka pisang nanas

1 Harga bahan baku relatif mahal terjangkau relatif mahal

2 Penyusutan bahan baku menjadi bahan jadi $70 \%$ $60 \% 80 \%$

3 Ketersediaan bahan baku musim panen singkat, harga bahan baku tidak menentu. Memiliki kecenderungan lebih mahal musim panen sepanjang tahun, harga bahan baku relatif murah musim panen singkat, harga bahan baku tidak menentu. Memiliki kecenderungan lebih mahal

Sumber: Data Primer, diolah 2016

Saat ini KUB Ayu sudah mulai memproduksi secara berkala produk kripik pisang mas dengan menggunakan penggorengan vakum. Kapasitas mesin yang kecil yakni $3 \mathrm{~kg}$ menjadikan KUB Ayu tidak dapat memproduksi kripik pisang dalam jumlah besar dalam waktu yang cepat. Untuk satu kali proses produksi pisang mas dibutuhkan waktu +90 menit, tingkat kevakuman di tabung penggorengan sebesar $70 \mathrm{cmHg}$ dengan suhu 80 0C. Proses produksi menggunakan penggorengan vakum selalu dilakukan bersamaan dengan memproduksi produk KUB Ayu yang lain seperti kripik pisang dengan penggorengan manual, kuping gajah dan 
Hesti Herminingsih. Faktor Produksi Usaha Ternak Itik Petelur Semi Intensif Di Kabupaten Jember.

ladrang. Hal ini dilakukan karena pada proses produksinya penggorengan vakum tidak memerlukan tenaga kerja yang intensif. Tenaga kerja hanya sesekali harus memutar tuas disamping kanan alat guna memberikan hasil gorengan yang merata.

Selain mendapatkan bantuan teknologi tepat guna, KUB Ayu juga memperoleh pelatihan Manajemen Persediaan Bahan Baku dan Administrasi Keuangan Sederhana untuk Usaha Kecil. Untuk manajemen persediaan bahan baku KUB Ayu telah dapat melaksanakan dengan baik. Adapun Administrasi Keuangan, KUB Ayu masih dalam tahap penyesuaian untuk menerapkan teori-teori yang diberikan pada saat pelatihan. Kendala yang paling sulit adalah memisahkan keuangan rumah tangga dengan usaha. Secara umum, KUB Ayu sangat terbantu dengan adanya kegiatan pengabdian kepada masyarakat yang dilaksanakan oleh Tim Abdimas. Setelah mengikuti kegiatan IbM ini, Efektifitas inovasi teknologi yang berhasil dilakukan oleh KUB Ayu secara lebih lengkap tersaji pada Tabel 3.2 berikut ini :

TABEL 3.2. HASIL CAPAIAN OLEH KUB AYU SEBELUM DAN SESUDAH IBM

\begin{tabular}{|c|c|c|}
\hline $\mathrm{N}_{0}$ & Sebelum Ib.II & Sesudah $\mathrm{Ib}_{\mathrm{b}} \mathrm{MI}$ \\
\hline & a.Penggorengan Vakum & \\
\hline 1. & $\begin{array}{l}\text { Penggorengan dilakukan dengan menggunakan wajan } \\
\text { dengan bahan bakar kayu yang suhunya tidak dapat } \\
\text { dikontrol }\end{array}$ & $\begin{array}{l}\text { Penggorengan dilakukan dengan } \\
\text { menggunakan tabung penggorengan hampa } \\
\text { dengan suhu yang dapat dikontrol }\end{array}$ \\
\hline 2. & $\begin{array}{l}\text { Minyak hasil penggorengan cepatrusak sehingga } \\
\text { hasil pangan mengalami perubahan cita rasa dan } \\
\text { tampilan hasil gorengan agak gosong }\end{array}$ & $\begin{array}{l}\text { Minyak hasil penggorengan tidakcepat rusak } \\
\text { sehingga hasil pangant tidakmengalami } \\
\text { perubahan citarasa dan tampilan hasil } \\
\text { gorengan tidak gosong }\end{array}$ \\
\hline \multirow[t]{2}{*}{3.} & $\begin{array}{l}\text { Terdapat hasil gorengan yang yang gosong dan tidak } \\
\text { layak djual }\end{array}$ & $\begin{array}{l}\text { Tidak terdapat hasil gorenganyang gosong } \\
\text { dan tidak layak dijual }\end{array}$ \\
\hline & $\begin{array}{l}\text { Produk tidak tahan lama karena kandunganminyak } \\
\text { yang tinggi }\end{array}$ & $\begin{array}{l}\text { Produk lebih tahan lama karena kandungan } \\
\text { minyak yang rendah }\end{array}$ \\
\hline 4. & $\begin{array}{l}\text { Dibutuhkan } 3 \text { (tiga) orang tenaga kerja dalam satu } \\
\text { kali proses penggorengan }\end{array}$ & $\begin{array}{l}\text { Dibutuhkan } 1 \text { (satu) orang tenaga kerja dalam } \\
\text { satukali proses penggorengan }\end{array}$ \\
\hline 5. & Suhu perapian tidak dapat dikontrol & Suhu perapian dapat dikontrol \\
\hline 6. & $\begin{array}{l}\text { Hasil gorengan tidak homogen dalam hal kualitas } \\
\text { tampilan dan cita rasa }\end{array}$ & $\begin{array}{l}\text { Hasil gorengan homogen dalam hal kualitas } \\
\text { tampilan dan cita rasa }\end{array}$ \\
\hline \multirow[t]{2}{*}{7.} & Kapasitas produksi 4 kg jam & Kapasitas produksi $6 \mathrm{~kg}$ jam \\
\hline & b. Pelatihan Manajemen Pengendalian Persediaan B & Bahan Baku dan Bahan Jadi \\
\hline 8 & $\begin{array}{l}\text { Peserta tidak dapat melaksanakan manajemen } \\
\text { pengendalian bahhan baku }\end{array}$ & $\begin{array}{l}\text { Peserta dapat melakssanakan manajemen } \\
\text { pengendalian bahan baku }\end{array}$ \\
\hline 9 & $\begin{array}{l}\text { Peserta tidak dapat melakukan manajemen } \\
\text { pengendalian bahan jadi }\end{array}$ & $\begin{array}{l}\text { Peserta dapat melakukan manajemen } \\
\text { pengendalian bahan jadi }\end{array}$ \\
\hline 10 & $\begin{array}{l}\text { Sering kesulitan mencari bahan baku terutama saat } \\
\text { permintaan produk sedang tinggi }\end{array}$ & $\begin{array}{l}\text { Tidak kesulitan dalam mencari bahan baku } \\
\text { terutama saatpemintaan sedang tinggi }\end{array}$ \\
\hline 11 & Sering terjadi kelebihan stok & Stok cukup \\
\hline 12 & $\begin{array}{l}\text { Ditemukan produk yang belum laku yang sudah } \\
\text { lewat tanggal kadaluarsa } \\
\text { c.Pelatihan Administrasi Keuangan }\end{array}$ & $\begin{array}{l}\text { Tidak ditemukan produk yang belum laku } \\
\text { yang sudahlewat tanggal kadaluarsa }\end{array}$ \\
\hline 13 & $\begin{array}{l}\text { Peserta tidak dapat melakukan pengadministrasi } \\
\text { keuanganusaha }\end{array}$ & $\begin{array}{l}\text { Peserta dapat melakukan pengadminstrasi } \\
\text { keuangan usaha }\end{array}$ \\
\hline 14 & $\begin{array}{l}\text { Peserta tidak dapat mengetahui struktur biaya dan } \\
\text { laba usaha secara berkala }\end{array}$ & $\begin{array}{l}\text { Peserta dapat mengetahui strultur biaya dan } \\
\text { laba usaha secara berkala }\end{array}$ \\
\hline
\end{tabular}

No Sebelum IbM Sesudah IbM

a.Penggorengan Vakum

1. Penggorengan dilakukan dengan menggunakan wajan dengan bahan bakar kayu yang suhunya tidak dapat dikontrol Penggorengan dilakukan dengan menggunakan tabung penggorengan hampa dengan suhu yang dapat dikontrol

2. Minyak hasil penggorengan cepatrusak sehingga hasil pangan mengalami perubahan cita rasa dan tampilan hasil gorengan agak gosong Minyak hasil penggorengan tidakcepat rusak sehingga hasil pangan tidakmengalami perubahan citarasa dan tampilan hasil gorengan tidak gosong

3. Terdapat hasil gorengan yang yang gosong dan tidak layak dijual Tidak terdapat hasil gorengan yang gosong dan tidak layak dijual

Produk tidak tahan lama karena kandungan minyak yang tinggi Produk lebih tahan lama karena kandungan minyak yang rendah

4. Dibutuhkan 3 (tiga) orang tenaga kerja dalam satu kali proses penggorengan Dibutuhkan 1 (satu) orang tenaga kerja dalam satu kali proses penggorengan

5. Suhu perapian tidak dapat dikontrol Suhu perapian dapat dikontrol

6. Hasil gorengan tidak homogen dalam hal kualitas tampilan dan cita rasa Hasil gorengan homogen dalam hal kualitas tampilan dan cita rasa

7. Kapasitas produksi 4 kg/jam Kapasitas produksi 6 $\mathrm{kg} / \mathrm{jam}$

b. Pelatihan Manajemen Pengendalian Persediaan Bahan Baku dan Bahan Jadi

8 Peserta tidak dapat melaksanakan manajemen pengendalian bahan baku Peserta dapat melaksanakan manajemen pengendalian bahan baku 9 Peserta tidak dapat melakukan manajemen pengendalian bahan jadi Peserta dapat melakukan manajemen pengendalian bahan jadi

10 Sering kesulitan mencari bahan baku terutama saat permintaan produk sedang tinggi Tidak kesulitan dalam mencari bahan baku terutama saat permintaan sedang tinggi

11 Sering terjadi kelebihan stok Stok cukup

12 Ditemukan produk yang belum laku yang sudah lewat tanggal kadaluarsa Tidak ditemukan produk yang belum laku yang sudah lewat tanggal kadaluarsa

c.Pelatihan Administrasi Keuangan

13 Peserta tidak dapat melakukan pengadministrasi keuangan usaha Peserta dapat melakukan pengadminstrasi keuangan usaha

14 Peserta tidak dapat mengetahui struktur biaya dan laba usaha secara berkala Peserta dapat mengetahui struktur biaya dan laba usaha secara berkala

Sumber : Data Primer diolah,2016. 


\section{BAB VI. KESIMPULAN DAN SARAN}

4.1 Kesimpulan

1. Diversifikasi produk olahan kripik buah seperti nangka, pisang mas dan nanas dapat dilakukan dengan menggunakan mesin penggorengan vakum.

2. Mesin penggorengan vakum (Vacuum frying) yang dibuat mempunyai kapasitas penggorengan 3 $\mathrm{kg}$ bahan baku. Tingkat penyusutan untuk nangka sebesar $70 \%$, pisang $60 \%$ dan nanas $80 \%$. Dengan waktu penggorengan selama 90 menit, suhu 80 0C dan tingkat kevakuman di tabung penggorengan sebesar $-70 \mathrm{cmHg}$.

3. Buah yang dipilih oleh mitra sebagai bahan baku kripik adalah pisang mas, dengan pertimbangan harga lebih terjangkau, penyusutan rendah dan tersedia sepanjang musim.

4. Pembuatan keripik pisang membutuhkan alat vacuum frying agar rasa dan warnanya tetap sesuai aslinya serta agar kandungan minyaknya tidak menempel di keripik salak maka dikeringkan dengan alat spinner.

4.2 Saran

Pendampingan yang intensif sangat diperlukan terutama dalam hal penerapan administrasi keuangan pada usaha kedua mitra. Peningkatan skala produksi untuk kepentingan usaha ke depan perlu untuk diupayakan terutama pada KUB Ayu karena penggorengan vakum yang dimiliki masih belum memenuhi syarat untuk tingkat skala usaha.

\section{UCAPAN TERIMAKASIH}

Ucapan terima kasih ditujukan kepada Direktorat Riset dan Pengabdian kepada Masyarakt Kementerian Riset, Teknologi, dan Pendidikan Tinggi yang telah membiayai kegiatna ini melalui Program Pengabdian kepada Masyarakat Mono Tahun Ipteks Bagi Masyarakat (IbM) Tahun Anggaran 2016 Nomor 23700/UN31.2/PM/2016 Tanggal 11 Juli 2016.

\section{DAFTAR PUSTAKA}

[1] Departemen Pertanian. 2002. Kebijaksanaan Nasional Penyelenggaraan Penyuluhan Pertanian, Deptan, Jakarta

[2] Mesin Penggoreng hampa. http:// id.wikipedia.org/wiki/Mesin_penggoreng_hampa

[3] Ketaren, S. 1986. Pengantar Teknologi Minyak dan Lemak Pangan. UI Press. Jakarta. Aneka Mesin. 2012.Sistem Vakum Pada Vacuum Frying. http://anekamesin.com/sistem-vacuum-frying.html. Diakses pada 31 Maret 2015.
[4]Sawitri, D. 2009. Perancangnan Sistem Informasi Manajemen Persediaan Barang "Electrolux Authorized Service CV Momentum Teknik. Artikel. http://www.gunadarma.ac.id. Diakses pada 30 Maret 2015.

[5] Mulyatiningsih, E. 2007. Diktat: Teknik-Teknik Dasar Memasak. Fakultas Teknik Universitas Negeri Yogyakarta. staff.uny.ac.id. Diakses pada 30 Maret 2015.

[6] Sunaryo, 2014. Rancang Bangun Mesin Penggorengan Vakum dan Pelatihan Diversifikasi Olahan Salak Pondoh di Desa Pekandangan Kabupaten Banjarnegara. Jurnal PPKM III. abcd.unsiq.ac.id. Diaksespada 20 Januari 2017. 